\title{
DISSOMIC DISORDERS ASSOCIATED WITH JUVENILE RHEUMATOID ARTHRITIS: IMPACT ON QUALITY OF LIFE
}

Elezarov AA, Kucheryavyy AS, Gumenyuk LN, Sorokina LE $\bowtie$, Arifdzhanova SR, Gerbali OYu

Vernadsky Crimean Federal University, Simferopol, Russia

\begin{abstract}
Dyssomnic disorders (DD) associated with juvenile rheumatoid arthritis (JRA) are some of the most common conditions that are difficult to endure and that lead to deconditioning. This study aimed to assess prevalence and structure of DD, their relationship with clinical picture peculiarities and contribution to deterioration of the quality of lives of JRA patients. At the 1st stage, we assessed prevalence of DD in a continuous sample of JRA patients and healthy children aged 8-16 years. At the $2^{\text {nd }}$ stage, we assessed DD structure, features associated with gender and age, connections to the key clinical characteristics of JRA and quality of life of the patients. In the context of the study, we used the SDSC sleep quality scale, the PedsQL 4.0 quality of life model, and the Ritchie index. DD develop in JRA patients 3.3 times more often than in healthy children (in $178(72.3 \%)$ and $93(22.2 \%)$ children, respectively). The DD registered were sleep initiation and maintenance disorders (54 cases, 22.0\%), respiratory disorders (32 cases, 13.0\%), sleep-to-wakefulness transition disorders (31 cases, 12.6\%), excessive sleepiness disorders (38 cases, $15.4 \%)$, combinations thereof (23, 9.3\%). Girls had sleep initiation and maintenance disorders more pronounced $(p=0.003)$, boys were more prone to excessive sleepiness $(p=0.008)$. The severity of DD increases with patients' age $(r=0.69 ; p=0.001)$ and JRA onset age $(r=0.71 ; p=0.001)$; they are also more severe in polyarticular JRA patients $(r=0.32 ; p=0.048)$. We have clarified the relationship between DD and indicators of inflammatory $(r=0.56 ; p=0.001)$ and Ritchie indices $(r=0.44 ; p=0.005)$, duration of morning stiffness $(r=0.49 ; p=0.029)$. The proven connection between DD and JRA entails the need for routine checks for DD in such patients, and, when discovered, DD should call for personalized therapeutic and diagnostic approach rather than be regarded as one of the JRA syndromes.
\end{abstract}

Keywords: juvenile rheumatoid arthritis, dyssomnic disturbances, quality of life

Author contribution: AA Elezarov, AS Kucheryavyy — data collection, analysis and interpretation; LN Gumenyuk — research concept and design; LE Sorokina, SR Arifdzhanova, OYu Gerbali — article preparation.

Compliance with ethical standards: the study was approved by the ethical committee of the S.I. Georgievsky Medical Academy of Vernandsky Crimean Federal University (Federal State Autonomous Educational Institution), minutes protocol \#9 of October 14, 2019); it was planned and conducted in accordance with the Declaration of Helsinki, with parents of all JRA patients and healthy children included in the study signing a voluntary informed consent.

$\varangle$ Correspondence should be addressed: Leia E. Sorokina Lenina bulvar, 5/7, Simferopol, Republic of Crimea, 295006; leya.sorokina@mail.ru

Received: 05.10.2020 Accepted: 24.10.2020 Published online: 14.11.2020

DOI: 10.24075/brsmu.2020.071

\section{ДИССОМНИЧЕСКИЕ РАССТРОЙСТВА ПРИ ЮВЕНИЛЬНОМ РЕВМАТОИДНОМ АРТРИТЕ: ВЛИЯНИЕ НА КАЧЕСТВО ЖИЗНИ}

\author{
А. А. Елезаров, А. С. Кучерявый, Л. Н. Гуменюк, Л. Е. Сорокина $\bowtie$, С. Р. Арифджанова, О. Ю. Гербали
}

Крымский федеральный университет имени В. И. Вернадского, Симферополь, Россия

\begin{abstract}
Диссомнические расстройства (ДР) при ювенильном ревматоидном артрите (ЮРА) - одно из наиболее распространенных, тяжело переносимых и дезадаптирующих состояний. Цель исследования - оценить распространенность и структуру ДР, их взаимосвязь с клиническими особенностями, вклад в снижение качества жизни у больных ЮРА. На І этапе оценивали распространенность ДР в сплошной выборке больных ЮРА и здоровых детей 8-16 лет. На II этапе у больных ЮРА с верифицированными ДР оценивали их структуру, гендерно-возрастные особенности, взаимосвязь с основными клиническими характеристиками ЮРА, качеством жизни больных. Применяли шкалу для оценки качества сна SDSC, опросник качества жизни PedsQL 4.0, индекс Ричи. У больных ЮРА ДР встречаются в 3,3 раза чаще, чем у здоровых детей (у 178 (72,3\%) и у 93 (22,2\%) соответственно). Спектр ДР был представлен расстройствами инициации и поддержания сна - 54 (22,0\%), расстройствами дыхания - 32 (13,0\%), расстройствами перехода сна в бодрствование - 31 (12,6\%), расстройствами чрезмерной сонливости - 38 (15,4\%) и их сочетаниями - 23 (9,3\%). У девочек больше выражены расстройства инициации и поддержания сна ( $p=0,003)$, у мальчиков - расстройства чрезмерной сонливости ( $p=0,008)$. Тяжесть ДР нарастает по мере увеличения возраста больных ( $r=0,69 ; p=0,001)$ и возраста дебюта ЮРА ( $r=0,71 ; p=0,001)$, при полиартикулярном варианте $(r=0,32 ; p=0,048)$. Уточнена связь ДР с показателями воспалительного ( $r=0,56 ; p=0,001)$, суставного индексов $(r=0,44 ; p=0,005)$ и продолжительностью утренней скованности ( $r=0,49 ; p=0,029)$. Наличие взаимосвязи ДР и ЮРА диктует необходимость проведения рутинной диагностики ДР у данной категории больных, при этом для ведения ДР необходимо применять скорее персонисицированный лечебно-диагностический подход, чем расценивать его в качестве одного из синдромов ЮРА.
\end{abstract}

Ключевые слова: ювенильный ревматоидный артрит, диссомнические расстройства, качество жизни

Вклад авторов: А. А. Елезаров, А. С. Кучерявый - сбор, анализ и интерпретация данных; Л. Н. Гуменюк - замысел и дизайн исследования; Л. Е. Сорокина, С. Р. Арифджанова, О. Ю. Гербали - подготовка статьи.

Соблюдение этических стандартов: исследование одобрено этическим комитетом Крымской медицинской академии имени С. И. Георгиевского ФГАОУ ВО «Крымский федеральный университет им. В.И. Вернадского» (протокол № 9 от 14 октября 2019 г.), спланировано и проведено в соответствии с Хельсинской декларацией Всемирной медицинской организации; родители всех больных ЮРА и здоровых детей, включенных в исследование, подписали добровольное информированное согласие.

$\varangle$ Для корреспонденции: Лея Евгеньевна Сорокина бульвар Ленина, 5/7, г. Симферополь, Республика Крым, 295006; leya.sorokina@mail.ru

Статья получена: 05.10.2020 Статья принята к печати: 24.10.2020 Опубликована онлайн: 14.11.2020 DOI: $10.24075 /$ vrgmu.2020.071 
Dyssomnic disorders (DD) associated with juvenile rheumatoid arthritis (JRA) are some of the most common conditions. They are difficult to endure and lead to deconditioning [1], which makes addressing them an important task from both medical and social points of view. DD entails significant aggravation of the course of underlying disease, modification of the clinical response to treatment and rehabilitation effectiveness deterioration [2]. In addition, DD worsen the child's daytime quality of life: the disorders contribute to the manifestation of or intensify daytime sleepiness, aggressiveness, chronic fatigue, attention deficit, and hamper performance at school [3]. Consequently, the quality of life of the patients deteriorates, they are less likely to stay committed to therapy, and see the associated expenditures going up. At the same time, the connection between existing DD and JRA manifestations, as well as the effect the combination has on the patients' quality of life, are often underestimated in clinical practice.

It is a known fact that JRA patients also suffer from DD, yet the data on their prevalence are contradictory. A number of published papers report DD developing in JRA patients 2.8 times more often than in healthy children of the same age $[4,5]$. Other data available point to comparability of DD occurrence in JRA patients to the general population indicators [6].

According to the study reports available, the predominant DD are night wakefulness and anxiety, parasomnia, periodic limb movements, respiratory arrest, early morning awakenings and daytime sleepiness [5]. However, it should be noted that most studies only compare DD in healthy children and JRA patients [7], and the influence of gender and age on the predominance of types of DD in this cohort of patients remains practically unexplored.

The pathophysiology of DD against the background of JRA is multifactorial, and its mechanisms are being studied. The available literature mainly discusses issues related to the cause-and-effect relationships between DD and pain [7]. A few studies consider interconnections DD have with the disease's duration and clinical characteristics [1]. However, the results presented are fragmentary and insufficient for unambiguous conclusions, the probable reasons for that being differences in samples and methodological approaches to research setup.

The effect JRA onset age has on DD type prevalence and manifestation severity has not been investigated in any of the studies. The question of how DD relates to the key characteristics of articular syndrome remains pressing and relevant. There are research reports stating DD influences the quality of life of JRA patients [2, 8], yet the data are isolated and conflicting.

The problem of DD in JRA patients is not adequately covered in the current scientific literature by Russian authors.

This study aimed to assess degree of occurrence and prevalence of types of $\mathrm{DD}$, analyze their relationship with clinical picture peculiarities and contribution to deterioration of the quality of lives of JRA patients.

\section{METHODS}

The study included two stages. At the first stage, we assessed the prevalence of DD in a continuous sample of JRA patients and healthy children. The second stage was a one-stage prospective study of JRA patients with comorbid dyssomnic disorders. The goal was to assess structure, gender and age characteristics of patients with DD, the connections these aspects have with the key historical data and clinical characteristics of JRA, as well as the quality of life of patients.

The study's continuous sample was comprised of 246 JRA patients (mean age of $12.6 \pm 2.4(10.2 ; 15.0)$ years old), including 140 girls (56.9\%) and 106 boys (43.1\%), and 420 healthy children (average age of $12.6 \pm 2.4(10.2 ; 15.0)$ years old), including 252 girls (60.0\%) and 168 boys (40.0\%) that met the inclusion criteria. The groups were comparable in gender $\left(p=0.95 ; \chi^{2}\right)$ and age $\left(p=0.91 ; \chi^{2}\right)$.

The inclusion criteria for JRA patients were: verified JRA; age 8 to 16 years; 1 year or more of the underlying disease course; informed consent to participate in the study.

The exclusion criteria were: concomitant chronic inflammatory diseases; mental disorders; systemic or intraarticular administration of glucocorticoids four weeks before the start of the study; refusal to participate in the clinical trial.

The inclusion criteria for healthy children were: age 7 to 16 years; absence of chronic diseases and allergic reactions; absence of infectious and acute diseases for two months before the study.

For the $2^{\text {nd }}$ stage of the study, 178 patients with DD verified at the $1^{\text {st }}$ stage were selected, with DD determined using the Sleep disturbance scale for children, SDSC. The patients were grouped by the type of DD: sleep initiation and maintenance disorders $(n=54)$, respiratory disorders $(n=41)$, sleep-to-wakefulness transition disorders $(n=36)$, excessive sleepiness disorders $(n=47)$. The groups were analyzed individually, depending on the type of DD identified. In order to level the effect combined DD types may have on the studied parameters, the analysis did not include patients who scored above the threshold on two or more subscales of SDSC.

JRA diagnosis, nature of its course and the activity status were established as prescribed in ICD-10 (class 8) [9], ARA [10] and EULAR [11] recommendations. The Ritchie index was used to assess the articular syndrome. SDSC enabled assessment of sleep disorders [12], while Pediatric quality of life inventory (PedsQL 4.0, form for children) allowed establishing the patients' quality of life (QOL) [13].

STATISTICA 8.0 software package (StatSoft Inc.; USA) was used to statistically process the data obtained. The values distribution was checked for conformity with the standard normal distribution with the help of Kolmogorov-Smirnov test. Since the majority of quantitative characteristics did not meet the normal distribution requirements, they were described using the median (Me) and quartiles (Me (25\%; 75\%)). Mann-Whitney $U$ test enabled comparison of quantitative characteristics of independent groups, while for qualitative characteristics we relied on the analysis of contingency tables using the $\chi^{2}$ (chi-square) test and the Fisher's exact test. Comparison of quantitative characteristics registered in dependent groups was enabled by the Wilcoxon test. The differences were considered significant at $p<0.05$. Spearmen's rank-order correlation backed assessment of relationships between the characteristics.

\section{RESULTS}

Two hundred and eleven (85.7\%) JRA patients complained about sleep problems, while in the group of healthy children this figure was 140 (33.4\%). With the difference being significant, parents of JRA patients reported the following more often than parents of the participating healthy children: frequent nocturnal awakenings $(p=0.009)$, shorter total sleep duration $(p<0.001)$, apnea episodes $(p=0.001)$, periodic limb movements $(p=0.006)$, bruxism $(p=0.009)$, daytime sleepiness $(p<0.001)$. SDSC allowed diagnosing DD in 178 (72.3\%) JRA patients and in 93 (22.2\%) healthy children $(p<0.001)$. In JRA patients, the DD were sleep initiation and maintenance disorders, respiratory disorders, sleep-to-wakefulness transition disorders, excessive sleepiness, as well as combinations thereof (Fig.). 
Compared to patients without sleep initiation and maintenance disorders (SI and MD) (mean SI and MD subscale score - $20.2(16.0 ; 22.0))$, those suffering from SI and MD (mean SI and MD subscale score - 25.7 (23.0; 28.0)) were significantly older, had JRA onset at a later time, suffered from the disease for a significantly longer period of time, had it in polyarticular form more often, had more affected joints, slept considerably less, exhibited bruxism episodes more often, with bruxism being more severe, suffered from postsomnic fatigue, had more severe nocturnal awakenings and excitement disorder (ED) manifestations, more severe pain, lower QOL emotional component (EC) and integral (IS) scores (Table 1).

Patients with respiratory disorders (RD) (mean score on the RD subscale - $10.6(9.0 ; 12.5))$, compared to patients without $\mathrm{RD}$ (mean score - $4.9(3.0 ; 6.7))$, were significantly younger, had the disease for a shorter period of time, took longer to fall asleep, had more severe nighttime restlessness and snoring, suffered from daytime sleepiness (its acute forms) more often, had excessive sleepiness disorders (ESD) more severe and scored lower on the QOL physical component (PC) scale (Table 2).

Patients with sleep-to-wakefulness transition disorders (SW TD) (mean score on the SW TD subscale - 26.5 (25.0; 27.0)), compared to the participants not suffering the condition (mean score - 18.2 (16.0; 20.0)) had the following distinctive characteristics: older age, significantly more frequent occurrence of oligoarticular variant of JRA, more frequent and severe difficulties with laying down to sleep, manifestations of problems with falling asleep, more frequent occurrence and higher severity of bruxism, nightmares, excessive sweating, difficult awakening, greater severity of periodic limb movements and frequent pose changes (PLM and FPC), severe excitement disorders and excessive sleepiness, more acute pain experienced, lower QOL social component (SC) score (Table 3).

Patients with ESD (mean score on the ESD subscale - 23.1 (21.0; 25.0)), compared with the study participants without ESD (mean score - 14.4 (12.0; 18.0)), were predominantly male, older, had the JRA onset earlier and life and lived with the condition for a longer period of time, woke up at night more

Sleep disturbance complaints

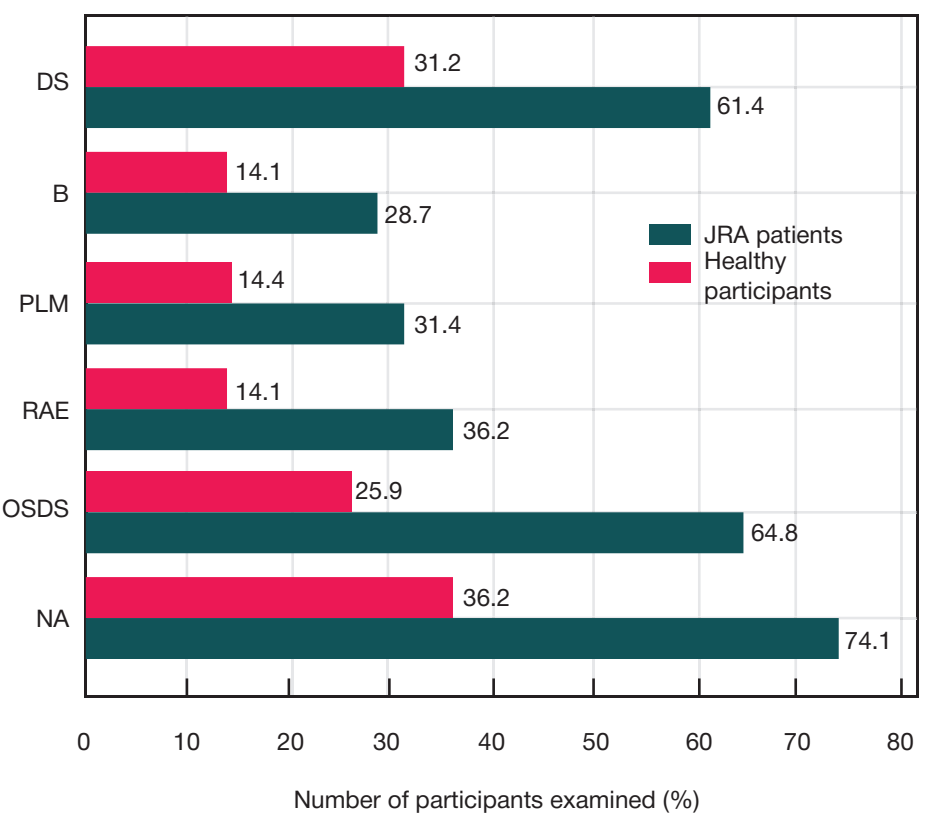

frequently, slept considerably less, woke up during the night more frequently and more often, stayed awake longer after falling asleep, exhibited more episodes of snoring, suffered more acute postsomnic asthenia, scored lower on the sleep quality scale, experienced pain more acutely, performed less well in school and scored lower on the integral QOL scale (Table 4).

In connection with the dependence of the course of many diseases on gender, the JRA patients' DD structural features and severity were analyzed with sexual dimorphism factored in. According to the data obtained, girls, compared to boys, were more prone to suffer from shorter sleep duration (73.7 (66.4\%) cases), nightmares (44 (39.9\%) cases) and postsomnic asthenia (79.0 (71.2\%) cases), while the respective figures reflecting same conditions in boys are $29(42.8 \%)$ cases (at $p=0.029), 16(23.6 \%)$ cases (at $p=0.048)$ and $30(44.9 \%)$ cases (at $p=0.001)$. The difference is significant. Girls have also shown a significantly greater number of nocturnal awakenings episodes $7.0(5.2 ; 7.8)$ versus $5.0(3.1 ; 6.4)$ in boys $(p=0.002),-$ and bruxism episodes - $4.5(3.0 ; 5.0)$ versus $3.3(2.0 ; 4.0)$ in boys $(p=0.019)$. Significant gender-driven differences were also registered in the prevalence of SI and $\operatorname{MD}(25.1(23 ; 28)$ in girls versus $23.0(21 ; 24)$ in boys, $p=0.003)$, and ESD (24.2 (22; 26) in boys versus $21,6(20 ; 23)$ in girls $(p=0.008)$.

Investigating the effect of age on the DD type prevalence, we established that the combination of SI and MD and SW TD symptoms was significantly more often registered in patients aged 15.7 (14.1; 16.0) compared to patients 10.9 (7.0; 14.0) years old; the scores were 37 (36.1\%) points versus 12 (16.4\%) points, respectively $(p=0.007)$. The integral sleep quality score (ISQS) was significantly lower in patients aged 8.6 (6.0; 10.4) compared with patients $13.7(10.1 ; 16.0)$ years old, the difference in points being 26.7 (22.4; 28.0) versus 32.2 (29.6; 35.8), respectively $(p<0.001)$. The correlations between age and frequency of nocturnal symptoms $(r=0.55 ; p=0.001)$ and DD manifestation intensity $(r=0.69 ; p=0.001)$ were found to be significant.

We have established a correlation between the JRA onset age and DD manifestation intensity: the values reflecting the

DD assessed with SDSC

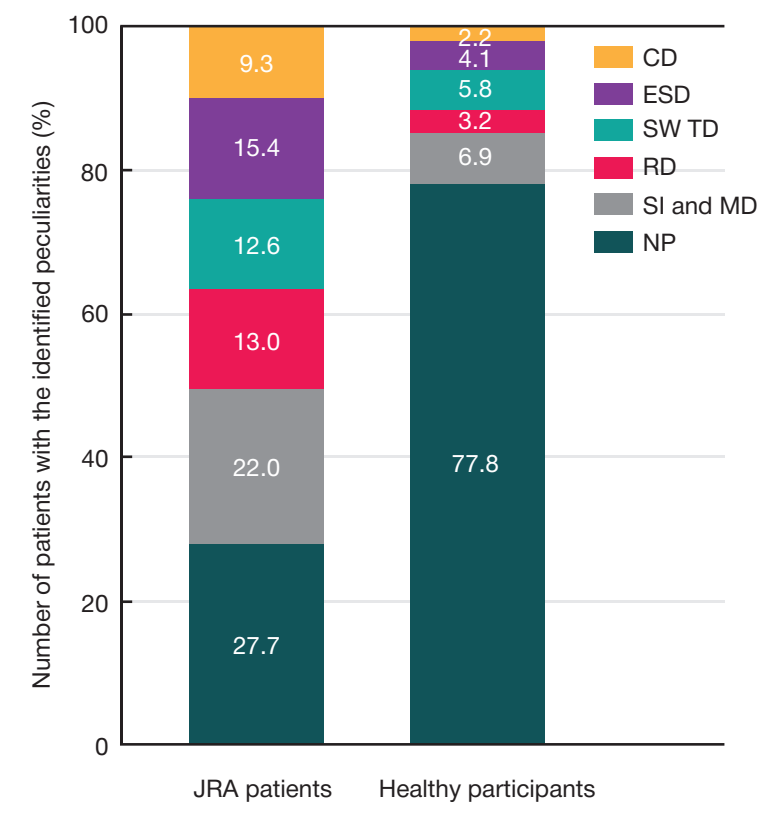

Fig. Structure of sleep disorders, JRA patients and healthy children. DD - dyssomnic disorders; NA — nocturnal awakenings; OSDS — overall sleep duration shortening; RAE — respiratory arrest episodes; PLM — periodic limb movements; B — bruxism; DS — daytime sleepiness; NP — no peculiarities; SI and MD — sleep initiation and maintenance disorders; RD — respiratory disorders; SW TD — sleep-to-wakefulness transition disorders; ESD — excessive sleepiness disorders; CD — concomitant disorders 
Table 1. Comparative analysis of patients with and without sleep initiation and maintenance disorders

\begin{tabular}{|c|c|c|c|}
\hline & $\begin{array}{l}\text { With SI and MD } \\
\qquad n=44\end{array}$ & $\begin{array}{l}\text { Without SI and MD } \\
\qquad n=96\end{array}$ & $p$ \\
\hline Age & $14.2(13.3 ; 16.0)$ & $8.1(7.0 ; 13.2)$ & $p=0.063^{\circ}$ \\
\hline JRA onset (age) & $11.4(6.0 ; 15.0)$ & $3.4(1.0 ; 5.0)$ & $p<0.001^{* \star *}$ \\
\hline JRA duration (years) & $6.2(5.8 ; 7.1)$ & $3.3(1.0 ; 4.6)$ & $p=0.006^{* *}$ \\
\hline Polyarticular variety (\%) & 62.4 & 33.2 & $p=0.008^{*}$ \\
\hline Over 4 affected joints (\%) & 71.4 & 42.6 & $p=0.044^{\circ}$ \\
\hline SDSC 1 Sleep duration (hours) & $5.4(5.0 ; 7.3)$ & $7.1(6.5 ; 8.2)$ & $p=0.001^{\star \star}$ \\
\hline SDSC 10 Nocturnal awakenings (points) & $4.1(4.0 ; 5.0)$ & $3.4(2.0 ; 4.0)$ & $p=0.002^{\star \star}$ \\
\hline Nocturnal awakenings (times per night) & $6.1(4.8 ; 7.4)$ & $4.2(3.2 ; 5.2)$ & $p=0.003^{\star *}$ \\
\hline SDSC 11 Wakefulness after falling asleep (points) & $4.2(3.0 ; 5.0)$ & $3.1(2.0 ; 4.0)$ & $p=0.011^{*}$ \\
\hline SDSC 19 Bruxism (points) & $3.5(2.0 ; 5.0)$ & $2.9(1.0 ; 4.0)$ & $p=0.007^{\star \star}$ \\
\hline SDSC 23 Postsomnic sleep fatigue (points) & $4.1(3.0 ; 5.0)$ & $2.8(2.0 ; 4.0)$ & $p=0.013^{\star \star}$ \\
\hline Postsomnic fatigue, yes/no (\%) & $78.9 / 21.1$ & $61.4 / 38.6$ & $p=0.006^{*}$ \\
\hline SDSC 24 Motor limitations during awakening (points) & $3.6(3.0 ; 4.0)$ & $1.8(1.0 ; 2.0)$ & $p=0.012^{*}$ \\
\hline Motor limitations during awakening, yes/no (\%) & $42.2 / 57.8$ & $12.1 / 87.9$ & $p<0.001 \cdots$ \\
\hline SDSC PB subscale (points) & $7.8(6.0 ; 9.0)$ & $4.2(1.0 ; 6.0)$ & $p=0.001^{\star \star}$ \\
\hline SDSC Integral indicator (points) & $54.4(52.0 ; 61.0)$ & $45.4(41.0 ; 50.0)$ & $p=0.009^{\star *}$ \\
\hline Pain index (points) & $3.1(2.0 ; 4.2)$ & $1.5(1.2 ; 1.8)$ & $p=0.034^{*}$ \\
\hline EC QOL (points) & $55.6(50.9 ; 61.0)$ & $66.8(60.0 ; 72.5)$ & $p=0.004^{\star \star}$ \\
\hline IA QOL (points) & $59.8(54.8 ; 64.7)$ & $67.1(62.1 ; 71.4)$ & $p=0.003^{\star \star}$ \\
\hline
\end{tabular}

Note: the values are given at $p<0.05 ;{ }^{*}-p<0.05$ (significance of differences estimated with Mann-Whitney $U$ test); ${ }^{* \star}-p<0.01$ (significance of differences estimated with Mann-Whitney $U$ test); ${ }^{* *}-p<0.001$ (significance of differences estimated with Mann-Whitney $U$ test); $-p<0.05$ (significance of differences estimated with $\chi^{2}$ test); $\cdots-p<0.05$ (significance of differences estimated with $\chi^{2}$ test); $\cdots-p<0.05$ (significance of differences estimated with $\chi^{2}$ test); $\mathrm{n}$ is the number of observations.

state of $\mathrm{SI}$ and $\mathrm{MD}, \mathrm{ESD}$, ISQS were significantly higher in patients that saw the onset of JRA at an older age (11.2 (10.0; 15.0) years) compared with the patients in whom the onset of JRA happened earlier $(5.6(1.0 ; 10.0)$ years), with the scores being 31.2 (26.2; 33.0), 25.1 (23.0; 27.4$)$ and $49.7(45.0 ; 52,1)$ points versus $24.6(22.1 ; 26.0)(p=0.008), 18.9(16.0 ; 20.2)$ $(p=0.006)$ and $35.9(32.0 ; 38.1)$ points $(p=0.001)$, respectively. The dependence of DD severity on the JRA onset age was confirmed by the significant correlation between the JRA onset age and the ISQS score established with the help of SDSC $(r=0.71 ; p=0.001)$.

The longer a patient had JRA, the more severe were sleep initiation and maintenance and excessive sleepiness disorders suffered by that patient: the SI and MD score in patients who had JRA for $8.3(6.1 ; 9.7)$ years was $32.2(29.0 ; 34,1)$ points, which is significantly higher than the same score shown by patients that had JRA for $2.2(1.0 ; 3.0)$ years, who scored $24.8(23.0 ; 26.1)$ points $(p=0.001)$, and those that suffered from the condition for $4.5(3.1 ; 6.0)$ years, the score of which was $28.4(24.0 ; 30.0)$ points $(p=0.008)$. As for the ESD, the scores were 22.9 (20.0; 23.4) points, 19.2 (15.0; 20.9) points $(p=0.048)$ and $16.5(14.4 ; 20.1)$ points $(p=0.005)$, respectively. Regardless of the types of DD registered and the manifestation intensity of the disorders, patients with JRA affecting their lives for 8.3 years exhibited a significantly shorter sleep duration compared to those who were living with the diseases for 2.2 $(1.0 ; 3.0)$ years, the figures being $6.6(5.0 ; 7.0)$ hours versus $8.6(8.0 ; 9.0)$ hours, respectively $(p=0.001)$. However, we found no correlation between ISQS score and duration of the disease: patients that had JRA for $2.2(1.0 ; 3.0)$ years scored

Table 2. Comparative analysis of patients with and without respiratory disorders

\begin{tabular}{|l|c|c|c|}
\multicolumn{1}{|c|}{ Parameters } & $\begin{array}{c}\text { With RD } \\
n=32\end{array}$ & $\begin{array}{c}\text { Without RD } \\
n=135\end{array}$ & $p$ \\
\hline Age (years) & $9.4(7.0 ; 11.6)$ & $15.8(11.7 ; 16.0)$ & $p=0.008^{* *}$ \\
\hline JRA duration (years) & $3.1(1.0 ; 4.2)$ & $5.7(3.0 ; 6.6)$ & $p=0.034^{\star}$ \\
\hline SDSC 2 Time needed to fall asleep (minutes) & $38.1(30.0 ; 42.4)$ & $51.4(47.2 ; 55.5)$ & $p=0.004^{\star *}$ \\
\hline SDSC 5 Nocturnal anxiety/fears (points) & $4.3(3.0 ; 5.0)$ & $3.4(2.0 ; 5.0)$ & $p=0.011^{\star}$ \\
\hline SDSC 14 Respiratory arrest (points) & $4.2(4.0 ; 5.0)$ & $2.2(2.0 ; 3.0)$ & $p=0.003^{\star *}$ \\
\hline SDSC 15 Snoring (points) & $3.5(3.0 ; 5.0)$ & $2.1(1.0 ; 3.0)$ & $p=0.008^{\star *}$ \\
\hline SDSC 25 Daytime sleepiness (points) & $4.2(3.0 ; 5.0)$ & $2.8(2.0 ; 4.0)$ & $p=0.003^{* *}$ \\
\hline Daytime sleepiness, yes/no (\%) & $62.5 / 37.5$ & $44.6 / 55.4$ & $p=0.046^{*}$ \\
\hline SDSC ESD subscale (points) & $16.4(13.0 ; 18.0)$ & $11.6(10.0 ; 14.0)$ & $p=0.009^{* \star}$ \\
\hline FC QOL (points) & $58.4(55.7 ; 60.0)$ & $63.1(61.1 ; 66.7)$ & $p=0.007^{\star *}$ \\
\hline
\end{tabular}

Note: the table shows values at $p<0.05 ;{ }^{*}-p<0.05$ (significance of differences estimated with Mann-Whitney $U$ test); ${ }^{* *}-p<0.01$ (significance of differences estimated with Mann-Whitney $U$ test); ${ }^{* \star}-p<0.001$ (significance of differences estimated with Mann-Whitney $U$ test); $-p<0.05$ (significance of differences estimated with $\chi^{2}$ test); $\cdots-p<0.05$ (significance of differences estimated with $\chi^{2}$ test); $\mathrm{n}$ is the number of observations (here and in tables $2-4$ ). 
$33.9(31.2 ; 36.8)$ points, those that had it for $4.5(3.1 ; 6.0)$ years scored $32.4(30.0 ; 35.8)$ points and patients that suffered from JRA for $8.3(6.1 ; 9.7)$ years showed the score of 35.1 (32.4; 36.9) points.

Investigating the relationship between JRA type and DD peculiarities, we discovered that patients with polyarticular JRA tended to wake up at night more frequently and had SI and MD manifesting more intensely than those who had oligoarticular JRA, the figures being 6.5 (3.8; 7.3) awakenings per night, 38.4 $(35.2 ; 40.1)$ points versus $5.7(3.4 ; 6.6)$ awakenings per night, 37.6 (33.9; 39.2) points, respectively. However, the difference was not significant. The daytime sleepiness index in patients with four or more affected joints was significantly higher than in patients with one to three joints affected: 4.4 (3.0; 5.0) points versus $3.1(2.2 ; 4,0)$ points, respectively $(p=0.004)$. Correlation analysis revealed a relationship between daytime sleepiness manifestation intensity and the number of affected joints: the more intense the former, the greater the number of the latter $(r=0.32 ; p=0.048)$.

More intense JRA symptoms were associated with more pronounced DD manifestations, but ISQS did not differ significantly depending on JRA intensity: children with JRA in remission had this indicator at $32.2(30.0 ; 34.1)$ points, those with the I degree JRA - at $33.1(30.9$; 34.8$)$ points, with the II degree - at 34.2 (30.0; 35.2) points, with the III degree JRA at $34.4(31.6 ; 36.0)$ points. The results of correlation analysis confirmed there is no relationship between the degree of JRA and the severity of DD.

Investigating the effect DD has of the JRA patients' QOL, we discovered the following: lower physical functioning scores correlated with shorter sleep time $(r=0.56 ; p=0.001)$, growing postsomnic fatigue $(r=-0.49 ; p=0.028), \operatorname{RD}(r=-0.46$; $p=0.001)$ and $\operatorname{ESD}(r=-0.73 ; p=0.0001)$, as well as lower ISQS $(r=-0.56 ; p=0.001)$. Emotional functioning scale score depended on the duration of sleep $(r=0.71 ; p=0.008)$, frequency of nocturnal awakenings $(r=-0.74 ; p=0.001)$, severity of bruxism $(r=-0.81 ; p=0.0001)$, SI and MD ( $r=-0.77$; $\left.p<10^{-6}\right)$ and ISQS $(r=-0.71 ; p=0.0001)$. Social functioning scale score correlated with the frequency of apnea episodes $(r=-0.44 ; p=0.012)$, postsomnic fatigue $(r=-0.55 ; p=0.001)$, daytime sleepiness $(r=-0.79 ; p=0.028)$, SI and MD $(r=-0.44$; $p=0.006)$, SW TD $(r=-0.68 ; p=0.012)$. School performance scores reflected the frequency of apnea episodes $(r=-0.67$; $p=0.001)$, severity of daytime sleepiness $(r=-0.88 ; p=0.006)$ and ESD ( $r=-0.92 ; p=0.008)$. Decreasing Integral Indicator of Quality of Life correlated with the growing SI and MD indicators $(r=-0.91 ; p=0.001)$, ISQS $\left(r=-0,91 ; p<10^{-6}\right)$.

\section{DISCUSSION}

It is a known fact that JRA patients also suffer from DD, yet the data on their prevalence and typical structure are scarce and fragmentary, and assumptions about their connection with the disease controversial. A number of studies report that, compared to healthy pees, JRA patients largely suffer from nocturnal wakefulness, restless sleep, respiratory disorders, periodic limb movements in sleep, and daytime sleepiness $[5-7,14]$. At the same time, the figures that are given as reflecting the occurrence of DD in JRA patients are comparable to those peculiar to the population in general [6]. Thus study shows that JRA patients have DD 3.3 times more often than their healthy peers (72.3 versus $22.2 \%)$. Our results are consistent with the data from earlier studies that established a high prevalence of DD among JRA patients (from 40 to $71.4 \%$ ) $[4,5]$ compared with the same age population groups not having JRA (25\%) [4].

According to our data, in JRA patients, the occurrence of periodic limb movements during sleep, nocturnal awakenings and daytime sleepiness exceeds the indices of healthy peers

Table 3. Comparative analysis of patients with and without sleep-to-wakefulness transition disorders

\begin{tabular}{|c|c|c|c|}
\hline Parameters & $\begin{array}{c}\text { With SW TD } \\
\quad n=26\end{array}$ & $\begin{array}{c}\text { Without SW TD } \\
n=114\end{array}$ & $p$ \\
\hline Age (years) & $15.2(14.0 ; 16.0)$ & $11.6(7.4 ; 13.9)$ & $p=0.048^{\circ}$ \\
\hline Oligoarticular variety, $n(\%)$ & $64.2 / 35.8$ & $32.1 / 67.9$ & $p=0.006^{\circ}$ \\
\hline SDSC 3 Difficulties with putting to bed (points) & $3.8(3.0 ; 5.0)$ & $1.9(1.0 ; 3.0)$ & $p=0.004^{\star \star}$ \\
\hline Difficulties with putting to bed, yes/no (\%) & $64.4 / 35.6$ & $22.9 / 77.1$ & $p=0.001^{\bullet}$ \\
\hline Difficulties with falling asleep, yes/no (\%) & $72.8 / 27.2$ & $42.5 / 57.5$ & $p=0.001^{\circ}$ \\
\hline SDSC 12 PLM and FPC (points) & $4.1(2.0 ; 5.0)$ & $2.2(1.0 ; 4.0)$ & $p=0.007^{\star \star}$ \\
\hline SDSC 16 Excessive sweating (points) & $3.4(2.0 ; 4.0)$ & $2.5(1.0 ; 3.0)$ & $p=0.011^{*}$ \\
\hline SDSC 16 Excessive sweating, yes/no (\%) & $46.6 / 53.4$ & $14.2 / 85.8$ & $p<0.001^{\cdots}$ \\
\hline SDSC 19 Bruxism (points) & $4.3(3.0 ; 5.0)$ & $2.9(1.0 ; 3.0)$ & $p=0.003^{\star \star}$ \\
\hline SDSC 19 Bruxism, yes/no (\%) & $88.6 / 11.4$ & $14.2 / 85.8$ & $p<0.001^{\cdots}$ \\
\hline SDSC 21 Nightmares (points) & $4.2(3.0 ; 4.0)$ & $2.8(2.0 ; 3.0)$ & $p=0.015^{*}$ \\
\hline Nightmares, yes/no (\%) & $51.1 / 48.9$ & $33.4 / 66.6$ & $p=0.019^{\circ}$ \\
\hline SDSC 22 Difficulties with waking up points & $4.5(4.0 ; 5.0)$ & $2.4(1.0 ; 3.0)$ & $p=0.005^{\star \star}$ \\
\hline Difficulties with waking up, yes/no (\%) & $81.7 / 18.3$ & $35.4 / 64.6$ & $p=0.006^{*}$ \\
\hline SDSC PB subscale (points) & $10.1(6.0 ; 12.0)$ & $8.1(4.0 ; 10.0)$ & $p=0.009^{\star \star}$ \\
\hline SDSC ESD subscale (points) & $19.2(16.0 ; 20.0)$ & $14.4(12.0 ; 18.0)$ & $p=0.006^{\star \star}$ \\
\hline Pain index (points) & $3.4(2.0 ; 4.5)$ & $2.5(2.2 ; 3.6)$ & $p=0.021^{*}$ \\
\hline EC QOL (points) & $55.6(50.9 ; 61.0)$ & $66.8(60.0 ; 72.5)$ & $p=0.005^{\star \star}$ \\
\hline SF QOL & $54.4(51.2 ; 57.8)$ & $66.4(61.1 ; 70.7)$ & $p=0.001^{\star \star}$ \\
\hline
\end{tabular}

Note: the table shows values at $p<0.05 ;{ }^{*}-p<0.05$ (significance of differences estimated with Mann-Whitney $U$ test); ${ }^{*}-p<0.01$ (significance of differences estimated with Mann-Whitney $U$ test); ${ }^{* *}-p<0.001$ (significance of differences estimated with Mann-Whitney $U$ test); $-p<0.05$ (significance of differences estimated with $\chi^{2}$ test); $\cdots-p<0.05$ (significance of differences estimated with $\chi^{2}$ test); $\cdots-p<0.05$ (significance of differences estimated with $\chi^{2}$ test); $\mathrm{n}$ is the number of observations. 
and confirms the viewpoint of a number of other researchers [5]. We did not confirm the high incidence of presomnic disorders (namely, difficulties with falling asleep) in JRA patients, which was reported in other studies [15]. According to our data, the figures reflecting prevalence of frequent nocturnal awakenings and their association with more pronounced daytime sleepiness are close to those obtained in two other studies $[5,16]$. In contrast to the already published results [1, 6, 14], which make parasomnia and respiratory disorders during sleep the most frequent manifestations of DD in JRA patients, we have discovered that such patients often sleep less in total, i.e. their overall sleep duration is shorter. Compared to their healthy peers, children with JRA and their parents report a significantly higher incidence of parasomnias in the form of nightmares and sleepwalking [7]. We have discovered that the predominant parasomnia in JRA patients is bruxism.

This study shows the connection between DD and patient gender. Girls were registered to more often suffer from shortened sleep duration, nightmares and post-sleep asthenia, they wake up and have bruxism episodes more often and suffer from more acute SI and MD, while boys tend to have ESD. These differences may be the result of both biological and psychosocial factors. Taking into account the results obtained and the therapy personalization trend, the question of the specificity of intergender differences in the manifestation and pathophysiological basis of DD associated with JRA needs further investigation. We have discovered how age affects the specifics of DD: the older the patients, the more often they have polymorphic variety of the disorder and the more severe are the dyssomnic manifestations. This result of our study disagrees with the report of one research effort that states inverse correlation between patients' age and sleep disorders [17].

Duration of the disease and clinical and anatomical features (variety, number of affected joints, process intensity) are considered to be the potential prerequisites that determine peculiarities of sleep disorders in JRA patients [1]. However, the data on the role played by these factors in sleep pattern changes are ambiguous.

It was established that patients with ESD score highest on the inflammatory index scale and have the longest periods of morning stiffness. JRA patients that had the disease onset later in their adolescence, between the ages of 11 and 15, suffer from more severe forms of SI and MD, ESD. The severity of DD increases together with the age at which the patient had the JRA onset, which is proved by a significant strong correlation between the age of JRA onset and ISQS as determined with SDSC. We did not find this fact reported in any similar work, therefore, it needs additional investigation.

This study has established that sleep duration decreases and SI and MD, ESD manifestation intensity increases as JRA matures. However, the relationship between ISQS and JRA duration has not been confirmed. The data obtained are close to the results indicating no or weak link between ISQS and the duration of the disease [18].

We have confirmed there are no differences in the intensity of DD depending on the suffered JRA variety, which was reported earlier [1]. Polyarticular JRA was established to be associated with the growing frequency of nocturnal awakenings and more intense SI and MD, but the association did not reach statistical significance. Some research reports confirm the link between DD types and the number of affected joints, but these results are contradictory [18]. In JRA patients, a clear relationship was established: the severity of daytime sleepiness increases as the number affected joints grows. The findings are consistent with the results of a study that reported higher PDSS (pediatric daytime sleepiness scale) scores shown by patients with polyarthritis [19]. Lack connection between the intensities of DD and JRA discovered by us is consistent with

Table 4. Comparative analysis of patients with and without excessive sleepiness disorders

\begin{tabular}{|c|c|c|c|}
\hline Parameters & $\begin{array}{c}\text { With ESD } \\
n=38\end{array}$ & $\begin{array}{c}\text { Without ESD } \\
\quad n=129\end{array}$ & $p$ \\
\hline Gender, male/female (\%) & $56.8 / 21.2$ & $33.2 / 66.8$ & $p=0.021^{\circ}$ \\
\hline Age (years) & $13.9(12.0 ; 16.0)$ & $9.2(7.0 ; 11.9)$ & $p=0.018^{\circ}$ \\
\hline JRA duration (years) & $5.8(3.5 ; 7.6)$ & $3.1(1.0 ; 4.4)$ & $p=0.016^{\star}$ \\
\hline JRA onset age & $3.9(1.0 ; 8.1)$ & $9.1(6.6 ; 16.0)$ & $p=0.002^{\star *}$ \\
\hline Activity degree I, $n(\%)$ & 34.6 & 55.2 & $p=0.027^{\bullet}$ \\
\hline Activity degree III, $n$ (\%) & 62.5 & 39.5 & $p=0.009^{*}$ \\
\hline SDSC 1 Sleep duration (hours) & $6.9(6.0 ; 7.5)$ & $8.4(8.0 ; 9.8)$ & $p=0.004^{\star \star}$ \\
\hline SDSC 10 Nocturnal awakenings (points) & $4.6(4.0 ; 5.0)$ & $3.1(2.0 ; 4.0)$ & $p=0.003^{* *}$ \\
\hline Nocturnal awakenings (times per night) & $7.3(5.2 ; 9.4)$ & $4.2(2.8 ; 5.6)$ & $p=0.003^{* *}$ \\
\hline Wakefulness after falling asleep (minutes) & $22.4 \pm 3.4$ & $10.2 \pm 1.8$ & $p<0.001^{\star \star \star}$ \\
\hline SDSC 14 Respiratory arrest, yes/no (\%) & $68.6 / 31.4$ & $39.5 / 60.5$ & $p<0.001^{\cdots}$ \\
\hline SDSC 15 Snoring (points) & $3.6(3.0 ; 5.0)$ & $2.2(1.0 ; 3.0)$ & $p=0.005^{\star \star}$ \\
\hline Snoring, yes/no (\%) & $56.7 / 43.3$ & $32.6 / 67.4$ & $p=0.006^{*}$ \\
\hline SDSC 23 Postsomnic sleep fatigue (points) & $4.6(4.0 ; 5.0)$ & $3.3(2.0 ; 4.0)$ & $p=0.012^{*}$ \\
\hline SDSC Integral indicator (points) & $63.1(60.0 ; 66.0)$ & $53.2(50.0 ; 60.0)$ & $p=0.001^{* \star}$ \\
\hline Inflammatory index (points) & $0.8(0.5 ; 0.9)$ & $0.6(0.3 ; 0.7)$ & $p=0.018^{*}$ \\
\hline Morning stiffness (minutes) & $48.6(44.2 ; 52.0)$ & $39.1(36.3 ; 40.2)$ & $p=0.001^{\star \star}$ \\
\hline SF QOL & $54.9(52.0 ; 58.5)$ & $62.2(58.4 ; 65.0)$ & $p=0.015^{\star}$ \\
\hline IA QOL (points) & $58.0(56.8 ; 60.7)$ & $66.1(64.0 ; 68.9)$ & $p=0.006^{\star \star}$ \\
\hline
\end{tabular}

Note: the table shows values at $p<0.05 ;{ }^{*}-p<0.05$ (significance of differences estimated with Mann-Whitney $U$ test); ${ }^{* *}-p<0.01$ (significance of differences estimated with Mann-Whitney $U$ test); ${ }^{* *}-p<0.001$ (significance of differences estimated with Mann-Whitney $U$ test); $\bullet-p<0.05$ (significance of differences estimated with $\chi^{2}$ test); $\cdots-p<0.05$ (significance of differences estimated with $\chi^{2}$ test); $\cdots-p<0.05$ (significance of differences estimated with $\chi^{2}$ test); $n$ is the number of observations. 
the data obtained in the context of study [1], which has shown no correlation between intensity of the disease activity and severity of sleep disorders as registered with CSHQ.

We have shown the multifactorial nature of DD in JRA patients and clarified the relationship of their manifestations with the main parameters of the articular syndrome. A number of studies interprets pain experienced by JRA patients as a predictor of sleep disorders [7, 8], but there is no evidence of a direct connection between pain and dyssomnic disorders. Most authors note that conceptual models of sleep disorders and pain imply complex, bi-directional relationships [14]. At the same time, it was shown that pain-dependent sleep quality deterioration in JRA patients is of greater prognostic significance, unlike the bi-directional influence in these relationships [20]. In our study, we have demonstrated that patients with $\mathrm{SI}$ and $\mathrm{MD}$ experience the most pronounced increase in the pain syndrome. We have also established a strong correlation between shortening of the overall sleep duration and aggravation of pain. This link was to be expected, since shorter sleep reinforces central sensitization, which any sensitivity threshold decrease is based on. The results obtained confirm the findings of the previous studies, which point out that self-assessment of the severity and frequency of pain largely (significantly) depends on the sleep structure and quality and distortions thereof $[1,6,7]$. However, the reported significant correlation between daytime sleepiness and pain severity [19] was not confirmed in our study. We have shown that ESD patients have the highest inflammatory index and morning stiffness duration figures. We did not find this fact stated in any similar work, which means it should be studied further.
An important result of this study is the clarification of the influence of DD manifestations on the JRA patients' quality of life parameters. It should be noted that studies covering the effect various JRA manifestations have on the quality of life provide varying assessments of DD's contribution thereto, with some naming them one of the key factors [2] and other discounting such disorders as the factors of low significance [8].

The inconsistency of data may be the result of heterogeneity in the population characteristics of the patients examined, as well as differences in the methodological approaches to setup of the studies. In our study, we have shown that JRA patients with concomitant SI and MD score poorly in terms of emotional functioning, those that have $\mathrm{RD}$ lack in physical functioning, patients with SW TD do not do well socially and those suffering from ESD underperform in school. We have also confirmed the relationship between DD intensity and the integral assessment of QOL. The significant negative effect DD has on the QOL indicators of JRA patients is the basis for development of the adequate remedial techniques.

\section{CONCLUSION}

Thus, the proven connection between DD and JRA entails the need for routine checks for DD in such patients. DD should call for personalized therapeutic and diagnostic approach rather than be regarded as one of the JRA syndromes. Further study of the relationship between DD and JRA should go beyond registration of epidemiological data and include investigation of the mechanisms of pathogenesis of these comorbidities.

\section{References}

1. Butbul AY, Stremler R, Benseler SM, et al. Sleep and fatigue and the relationship to pain, disease activity and quality of life in juvenile idiopathic arthritis and juvenile dermatomyositis. Rheumatology. 2011; 50 (11): 2051-60. DOI: 10.1093/rheumatology/ker256.

2. Stinson JN, Hayden JA, AholaKohut S, Soobiah C, et al. Sleep problems and associated factors in children with juvenile idiopathic arthritis: a systematic review. Pediatric Rheumatology. 2014; 12 (1): 19. DOI: 10.1186/1546-0096-12-19.

3. Meltzer LJ, Mindell JA. Sleep and sleep disorders in children and adolescents. Psychiatr Clin North Am. 2006; 29 (4): 1059-76. DOI: 10.1016/j.psc.2006.08.004.

4. Tarakci E, Arman N, Barut K, et al. Fatigue and sleep in children and adolescents with juvenile idiopathic arthritis: a cross-sectional study. Turk J Med Sci. 2019; 49: 58-65, DOI: 10.3906/sag-1711-167.

5. Ward TM, Sonney J, Ringold S, et al. Sleep Disturbances and Behavior Problems in Children with and without Arthritis. J Pediatr Nurs. 2014; 29 (4): 321-8. DOI: 10.1016/j.pedn.2014.03.022.

6. Bromberg MH, Gil KM, Schanberg LE. Daily sleep quality and mood as predictors of pain in children with juvenile polyarticular arthritis. Health Psychol. 2012; 31 (2): 202-9. DOI: 10.1037/ a0025075.

7. Bloom BJ, Owens JA, McGuinn M, et al. Sleep and its relationship to pain, dysfunction, and disease activity in juvenile rheumatoid arthritis. J Rheumatol. 2002; 29 (1): 169-73. DOI: 10.1007/ s10067-013-2409-X.

8. Chen X, Sekine M, Hamanishi S, et al. Associations of lifestyle factors with quality of life (QOL) in Japanese children: a 3-year follow-up of the Toyama Birth Cohort Study. Child Care Health Dev. 2005; 31: 4339. DOI: 10.1111/j.1365-2214.2005.00529.x.

9. Ovcharov VK, Maksimov MV. Spravochnik Mezhdunarodno statisticheskoj klassifikacii boleznej i problem, svjazannyh so zdorov'em, 10-go peresmotra (MKB-10). Rossijskaja akademija medicinskih nauk, NII social'noj gigieny, jekonomiki i upravlenija zdravoohraneniem im. NA Semashko. 2011, 593 s. Russian.

10. Arnett FC, Edworthy SM, Bloch DA, et al. The American Rheumatism Association 1987 revised criteria for the classification of rheumatoid arthritis. Arthritis Rheum. 1988; 31: 315-24. DOl: 10.1002/art.1780310302.

11. Aletaha D, Neogi T, Silman AJ, et al. Rheumatoid arthritis classification criteria: an American College of Rheumatology. European League Against Rheumatism collaborative initiative. Arthritis Rheum. 2010; 62: 569-81. DOI: 10.1002/art.27584.

12. Bruni O, Ottaviano S, Guidetti $\mathrm{V}$, et al. The Sleep Disturbance Scale for Children (SDSC). Construction and validation of an instrument to evaluate sleep disturbances in childhood and adolescence. $J$ Sleep Res.1996; 5: 251-61.

13. Varni J, Seid M, Kurtin P. The PedsQL 4.0: Reliability and validity of the Pediatric Quality of Life Inventory Version 4.0 Generic Core Scales in healthy and patient populations. Medical Care. 2001; 39: 800-12. DOI: 10.1097/00005650-200108000-00006.

14. Ward TM, Ringold S, Metz J, et al. Sleep disturbances and neurobehavioral functioning in children with and without juvenile idiopathic arthritis. Arthritis Care Res. 2011; 63 (7): 1006-12. DOI: 10.1002/acr.20469.

15. Biggs SN, LushingtonK, Cameron J, et al. Inconsistent sleep schedules and daytime behavioral difficulties in school-aged children. Sleep Medicine. 2011; 12 (8): 780-6. DOI: 10.1016/j. sleep.2011.03.017

16. Ringold S, Ward TM, Wallace CA. Disease activity and fatigue in juvenile idiopathic arthritis. Arthritis Care Res. 2013; 65 (3): 391-7. DOI: 10.1002/acr.21801.

17. Long AC, Krishnamurthy V, Palermo TM: Sleep disturbances in school-age children with chronic pain. J Pediatr Psychol. 2008; 33 (3): 258-68. DOI: 10.1093/jpepsy/jsm129.

18. Zamir G, Press J, Tal A, Tarasiuk A. Sleep fragmentation in children with juvenile rheumatoid arthritis. J Rheumatol.1998; 25 (6): 1191-7. 
19. Amos CE, Curry MR, Drutz IE, Frost JD, Warren RW. Sleep disruption in school-aged children with JRA [abstract]. Arthritis Rheum. 1997; 40 Suppl: S244.

\section{Литература}

1. Butbul AY, Stremler R, Benseler SM, et al. Sleep and fatigue and the relationship to pain, disease activity and quality of life in juvenile idiopathic arthritis and juvenile dermatomyositis. Rheumatology. 2011; 50 (11): 2051-60. DOI: 10.1093/rheumatology/ker256.

2. Stinson JN, Hayden JA, AholaKohut S, Soobiah C, et al. Sleep problems and associated factors in children with juvenile idiopathic arthritis: a systematic review. Pediatric Rheumatology. 2014; 12 (1): 19. DOI: 10.1186/1546-0096-12-19.

3. Meltzer LJ, Mindell JA. Sleep and sleep disorders in children and adolescents. Psychiatr Clin North Am. 2006; 29 (4): 1059-76. DOI: 10.1016/j.psc.2006.08.004.

4. Tarakci E, Arman N, Barut K, et al. Fatigue and sleep in children and adolescents with juvenile idiopathic arthritis: a cross-sectional study. Turk J Med Sci. 2019; 49: 58-65, DOI: 10.3906/sag-1711-167.

5. Ward TM, Sonney J, Ringold S, et al. Sleep Disturbances and Behavior Problems in Children with and without Arthritis. J Pediatr Nurs. 2014; 29 (4): 321-8. DOI: 10.1016/j.pedn.2014.03.022.

6. Bromberg MH, Gil KM, Schanberg LE. Daily sleep quality and mood as predictors of pain in children with juvenile polyarticular arthritis. Health Psychol. 2012; 31 (2): 202-9. DOI: 10.1037/ a0025075.

7. Bloom BJ, Owens JA, McGuinn M, et al. Sleep and its relationship to pain, dysfunction, and disease activity in juvenile rheumatoid arthritis. J Rheumatol. 2002; 29 (1): 169-73. DOI: 10.1007/ s10067-013-2409-X.

8. Chen X, Sekine M, Hamanishi S, et al. Associations of lifestyle factors with quality of life (QOL) in Japanese children: a 3-year follow-up of the Toyama Birth Cohort Study. Child Care Health Dev. 2005; 31: 4339. DOI: 10.1111/j.1365-2214.2005.00529.x.

9. Овчаров В. К., Максимов М. В. Справочник Международной статистической классификации болезней и проблем, связанных со здоровьем, 10-го пересмотра (МКБ-10). Российская академия медицинских наук, НИИ социальной гигиены, экономики и управления здравоохранением им. $\mathrm{H}$. А. Семашко. 2011, 593 с.

10. Arnett FC, Edworthy SM, Bloch DA, et al. The American Rheumatism Association 1987 revised criteria for the classification
20. Valrie CR, Bromberg MH, Palermo T, Schanberg LE. A systematic review of sleep in pediatric pain populations. J Dev Behav Pediatr. 2013; 34 (2): 120-8. DOI: 10.1097/DBP.0b013e31827d5848.

of rheumatoid arthritis. Arthritis Rheum. 1988; 31: 315-24. DOl: 10.1002/art.1780310302.

11. Aletaha D, Neogi T, Silman AJ, et al. Rheumatoid arthritis classification criteria: an American College of Rheumatology. European League Against Rheumatism collaborative initiative. Arthritis Rheum. 2010; 62: 569-81. DOI: 10.1002/art.27584.

12. Bruni $\mathrm{O}$, Ottaviano S, Guidetti V, et al. The Sleep Disturbance Scale for Children (SDSC). Construction and validation of an instrument to evaluate sleep disturbances in childhood and adolescence. $J$ Sleep Res.1996; 5: 251-61.

13. Varni J, Seid M, Kurtin P. The PedsQL 4.0: Reliability and validity of the Pediatric Quality of Life Inventory Version 4.0 Generic Core Scales in healthy and patient populations. Medical Care. 2001; 39: 800-12. DOI: 10.1097/00005650-200108000-00006.

14. Ward TM, Ringold S, Metz J, et al. Sleep disturbances and neurobehavioral functioning in children with and without juvenile idiopathic arthritis. Arthritis Care Res. 2011; 63 (7): 1006-12. DOI: 10.1002/acr.20469.

15. Biggs SN, LushingtonK, Cameron J, et al. Inconsistent sleep schedules and daytime behavioral difficulties in school-aged children. Sleep Medicine. 2011; 12 (8): 780-6. DOI: 10.1016/j. sleep.2011.03.017.

16. Ringold S, Ward TM, Wallace CA. Disease activity and fatigue in juvenile idiopathic arthritis. Arthritis Care Res. 2013; 65 (3): 391-7. DOI: 10.1002/acr.21801.

17. Long AC, Krishnamurthy V, Palermo TM: Sleep disturbances in school-age children with chronic pain. J Pediatr Psychol. 2008; 33 (3): 258-68. DOI: 10.1093/jpepsy/jsm129.

18. Zamir G, Press J, Tal A, Tarasiuk A. Sleep fragmentation in children with juvenile rheumatoid arthritis. J Rheumatol.1998; 25 (6): 1191-7.

19. Amos CE, Curry MR, Drutz IE, Frost JD, Warren RW. Sleep disruption in school-aged children with JRA [abstract]. Arthritis Rheum. 1997; 40 Suppl: S244.

20. Valrie CR, Bromberg MH, Palermo T, Schanberg LE. A systematic review of sleep in pediatric pain populations. J Dev Behav Pediatr. 2013; 34 (2): 120-8. DOI: 10.1097/DBP.0b013e31827d5848. 